РОЗВИТОК ТВОРЧОГО ПОТЕНЦІАЛУ МАЙБУТНІХ ВИХОВАТЕЛІВ ЗАКЛАДІВ ДОШКІЛЬНОЇ ОСВІТИ У ПРОЦЕСІ ПРОФЕСІЙНОЇ ПІДГОТОВКИ

\title{
THE DEVELOPMENT OF CREATIVE POTENTIAL OF FUTURE PRESCHOOL EDUCATORS IN THE PROCESS OF PROFESSIONAL TRAINING
}

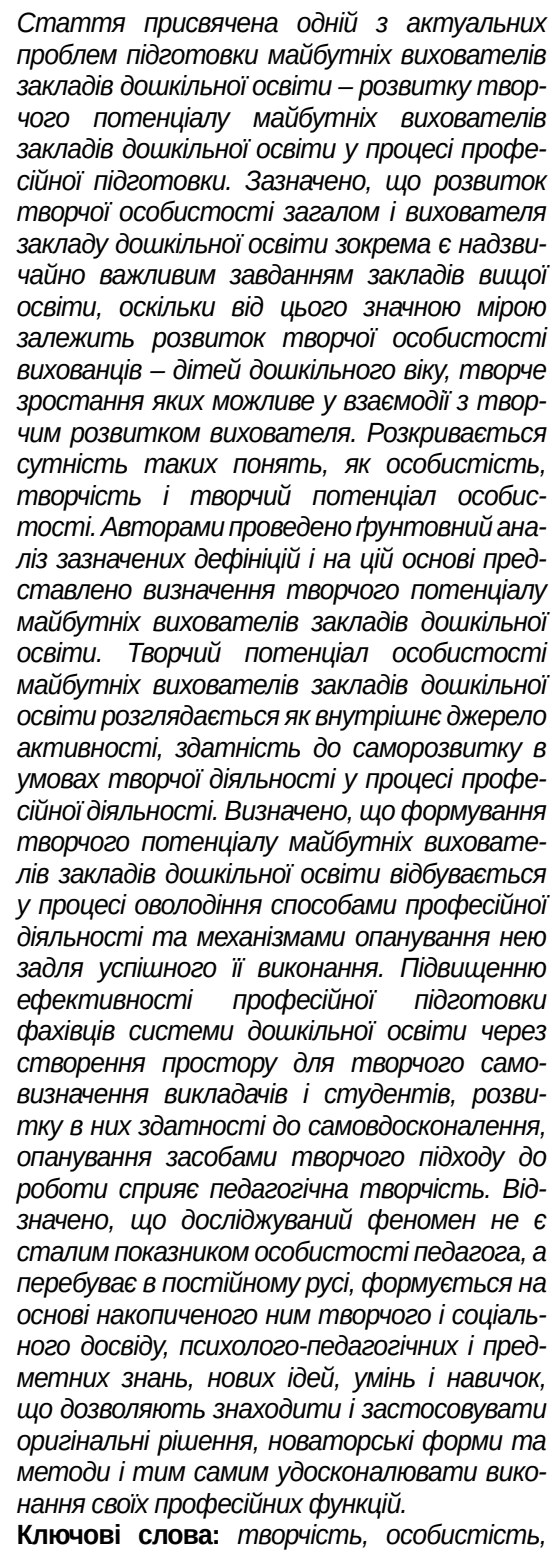
творчий потенціал особистості, майбутні вихователі закладів дошкільної освіти, професійна підготовка.

The article has been devoted to one of the most actual problems of preparation of future preschool educators, such as development of creative potential of future preschool educators in the process of professional training. It has been noted that the development of creative personality in general and the preschool educator in particular, is an extremely important task of higher educational establishments, since the development of the creative pupils' personality, whose creative growth is possible, above all, in interaction with creative, depends to a large extent development of the tutor. It has been revealed the sence of such conceptions as personality, creativity and creative potential of personality. The authors have conducted a thorough analysis of these definitions and on this basis presented the definition of the creative potential of future preschool educators. The creative potential of the personality of future preschool educators has been considered as an internal source of activity, the ability to self-development in the conditions of creative activity in the process of professional activity. It has been determined that the formation of creative potential of future preschool educators is in the process of mastering the methods of professional activity and the mechanisms of mastering in order to successfully fulfill it. Pedagogical creativity contributes to improving the effectiveness of vocational training of preschool education professionals through the creation of space for the creative self-determination of teachers and students, the development of the ability to self-improvement, mastering the means of creative approach to work. It has been noted that the phenomenon under study is not a permanent indicator of teacher's personality, but is in constant motion, formed on the basis of his creative and social experience, psychological and pedagogical and subject knowledge, new ideas, skills and abilities that allow to find and apply original solutions, innovative forms and methods, and thus improve the performance of their professional functions.

Key words: creativity, personality, creative potential of the individual, future preschool educators, professional training.
Постановка проблеми у загальному вигляді. Вітчизняна система освіти сьогодні спрямована на реформування дошкільної галузі, що передбачає актуалізацію тенденції створення національного освітнього простору шляхом інтегрування інноваційних технологій не лише в загальну професійну підготовку майбутніх педагогів, а й у їхню підготовку до творчого удосконалення навчального процесу. Це висуває певні вимоги до підготовки вихователів дітей дошкільного віку, які спроможні виконувати покладені на них професійні обов'язки на високому рівні, знаходити нестандартний, творчий, креативний і найбільш ефективний спосіб вирішення освітніх завдань, тим самим фрормуючи творчу особистість дитини-дошкільника.

Аналіз останніх досліджень і публікацій. Профресійна підготовка майбутніх вихователів $€$ предметом дослідження Л. Атремової, Г. Бєлєнької, Н. Грами, О. Дубасенюк, Л. Зданевич, К. Крутій, В. Нестеренко, Т. Поніманської та ін. Проблема розвитку творчого потенціалу особистості досліджується у фрілософрсько-культурологічному (М. Євтух, М. Коган, В. Кремень, П. Саух, В. Сухомлинський, О. Сухомлинська, Г. Філіпчук, В. Франкл, Е. Фромм та ін.), психолого-педагогічному (Б. Ананьєв, В. Андрущенко, Г. Балл, І. Бех, Л. Виготський, 
В. Загв'язинський, І. Зязюн, Г. Костюк, Н. Кузьміна, А. Леонтьєв, Б. Ломов, В. Мерлін, Н. Ничкало, А. Петровський, С. Рубінштейн. С. Сисоєва та ін.) напрямах. Незважаючи на наявні наукові напрацювання, проблема розвитку творчого потенціалу вихователів закладів дошкільної освіти у процесі професійної підготовки, на нашу думку, розкрита недостатньо ґрунтовно.

Виділення не вирішених раніше частин загальної проблеми. Аналіз наукових праць свідчить, що проблема розвитку творчого потенціалу майбутніх вихователів закладів дошкільної освіти у процесі професійної підготовки не була предметом цілісного наукового дослідження. Це негативно впливає на якість професійної підготовки майбутніх вихователів закладів дошкільної освіти, які не володіють актуальним рівнем творчого потенціалу, необхідним для здійснення ефективної профресійної діяльності.

Мета статті - обґрунтувати теоретичні аспекти розвитку творчого потенціалу майбутніх вихователів закладів дошкільної освіти у процесі профресійної підготовки.

Виклад основного матеріалу. Розвиток творчої особистості загалом і вихователя закладу дошкільної освіти зокрема $€$ надзвичайно актуальною проблемою сьогодення, оскільки від цього значною мірою залежить і розвиток творчої особистості вихованців - дітей дошкільного віку. Відповідно метою професійної підготовки майбутніх вихователів закладів дошкільної освіти є озброєння педагогічними знаннями та практичними вміннями, що необхідні для забезпечення високого рівня профресійної діяльності, впливають на підвищення педагогічної майстерності та фрормування значущих професійно-педагогічних якостей, однією з яких є творчий потенціал.

Аналіз наукової літератури показав наявність різноаспектних підходів до визначення сутності поняття «творчий потенціал особистості», яке нерозривно пов'язане з поняттями «особистість» і «творчість». Розглянемо найбільш актуальні для нашого дослідження.

Інтерпретація категорії «особистість» - складна та мінлива. Вона змінюється разом зі змінами суспільства й етносу, до якого вона належить. Особистість завжди фрункціонує у певному історичному часі. Вона може його випереджувати чи відставати від нього, але завжди тією чи іншою мірою залишається сучасною, не просто йде з часом поряд, а є заглибленою у сучасність, тим самим стимулюючи зміни в суспільстві [6, с. 33]. О. Злобіна визначає активну людину як соціально успішну, здатну використати свій особистісний потенціал, реалізувати себе як фрахівця у процесі демонстрації високого рівня особистісної суб'єктності [7, с. 26].

О. Клепікова та І. Кучерявий вважають, що творчість виникає у процесі становлення люд- ського індивіда як представника людської спільноти. Для того, щоб цей процес не припинявся й активно розвивався, на думку науковців, кожному індивіду необхідне забезпечення можливості реалізувати себе, в т. ч. й у творчій діяльності [8, с. 19]. Погоджуємося 3 О. Ємчик, що творчий початок потенційно закладено в кожному індивіді, й основне питання полягає в тому, наскільки він реалізується, стає визначальним у діях, вчинках і житті людини. Верхньою межею творчих досягнень особистості $€$ удосконалення життя усього людства, інноваційне прискорення його соціальної та культурної еволюції та вдосконалення себе як суб'єкта суспільного буття [6, с. 38].

Поняття «творчість» широко використовується у повсякденному житті та науковій літературі. Проте є труднощі щодо його значення. До основних понять «творчості» належать такі: Творчість - це діяльність людини, в якій вона створює нові об'єкти та якості, схеми поведінки й спілкування, нові образи та знання; Творчість є вищою фрормою активності та самодіяльності людини; Творчість - це суто людська діяльність; це не лише створення суспільно значущого продукту, творчістю можна назвати всі ті «відкриття», які людина робить особисто для себе; творчими є майже всі психічні процеси, за винятком, може, автоматизованих дій; Творчість - це потреба в самоактуалізації, повній і вільній реалізації своїх здібностей і життєвих можливостей [2, с. 3].

На думку С. Рубінштейна, творчість - діяльність людини, котра створює нові матеріальні та духовні цінності, які, у свою чергу, мають суспільну значимість [14, с. 45]. В. Сухомлинський, надаючи величезного значення творчості у педагогічній праці, порівнює її 3 «живою водою», яка дає свіжі сили і допомагає долати труднощі [16, с. 403], та вважає, що творчість починається там, де інтелектуальні й естетичні багатства, напрацьовані раніше, стають засобом пізнання, опанування, перетворення світу, людська особистість ніби зливається зі своїм духовним надбанням [16, с. 405].

Найбільш ґрунтовною є думка В. Кременя, що творчість - це апогей людського існування, коли людина набуває здатності перетворювати дійсність (відносини, норми, цінності), у якій здійснює життєдіяльність. Крім того, творчість - це поліфункціональна категорія, яка характеризує різні форми взаємовідносин особистості із собою та суспільством, тому вона постає як культурологічна, соціально-історична, онтологічна, естетична та психологічна категорія [10, с. 7-8].

Аналізуючи наведені визначення, робимо висновок, що творчість - це людська діяльність, у процесі якої особистість, задовольняючи потреби в реалізації своїх здібностей, створює нові знання, об'єкти, схеми поведінки, робить власні «відкриття». Творчість - діяльність людини, 
спрямована на створення якісно нових, невідомих раніше духовних або матеріальних цінностей.

Вихователь закладу дошкільної освіти - це професійна роль, яка полягає у прийнятті на себе повної міри відповідальності за умови, характер і перспективи розвитку особистості дитини та їі творчого начала. Вважаємо, що тільки вихователь, особистість якого є творчою та володіє творчим потенціалом, спроможний забезпечити виконання цього нелегкого завдання.

Педагогічний словник визначає творчу особистість як особистість, що має «здібності, мотиви, знання й уміння, завдяки яким створюється продукт, що відрізняється новизною, оригінальністю, унікальністю» [4, с. 186].

Узагальнюючи фрілософські, психологічні, педагогічні підходи до розуміння сутності творчого потенціалу людини як фундаментальної наукової категорії, О. Гопка вважає за необхідне підкреслити інтегративну властивість цього особистісного утворення, яка характеризує міру можливостей людини здійснювати творчу діяльність, визначає іiі готовність і здатність до творчої самореалізації й саморозвитку. Творчий потенціал особистості, з одного боку, виступає важливою передумовою творчого процесу, а 3 іншого - його результатом. І чим більше ресурсів реалізує особистість у власному житті, тим багатшим стає її творчий потенціал, набувається творчий стиль життя як життєтворчість [5, с. 12].

В енциклопедичному словнику творчий потенціал (creativity) - це винахідливість у науці та мистецтві, вміння бачити нове у звичних речах і наявність вільної гри уяви, рідкісна якість, притаманна не лише талановитим особистостям, але й і звичайним людям, яка реалізується за сприяння освіти в поєднанні 3 натхненням і наполегливою працею [3].

Сутність творчого потенціалу як сукупності наявних особистісних можливостей, на думку М. Алексеєвої, полягає у можливості організації системи певних умов, спрямованих на розвиток прихованих можливостей, що не проявляються в об'єкті буття, який можна сприйняти й описати $[1$, с. 67].

Творчий потенціал як сукупність творчих здібностей, необхідних для творчої діяльності, як зазначає В. Лихвар, є рушійною силою і ядром реалізації творчого потенціалу. Внутрішні фрактори особистості $€$ важливими чинниками саморозвитку людини, самореалізації, самодіяльності, вільних дій і вчинків [11, с. 17].

Формування творчого потенціалу майбутніх вихователів закладів дошкільної освіти відбувається у процесі оволодіння способами професійної діяльності та механізмами опанування нею задля успішного її виконання, адже ця діяльність, як справедливо зауважує Т. Лісовська, - це осо- бливий вид профресійної діяльності, зміст якої передбачає необхідність мати глибокі педагогічні знання, хороші організаторські здібності, володіти вміннями творчо здійснювати виховний процес 3 урахуванням психології дитячого колективу, соціальних, сімейних умов, в яких зростає і виховується підростаюче покоління [12, с. 103].

Ґрунтовні дослідження цілісної підготовки вчителя до педагогічної творчості здійснено С. Сисоєвою. Дослідниця вважає, що педагогічна творчість займає особливе місце серед різних видів творчості, оскільки саме вона визначає вектори динамічного розвитку всіх творчих процесів людства. Носієм педагогічної творчості є вчитель, який стоїть біля витоків розвитку особистості кожної людини [15, с. 11].

У межах нашого дослідження актуальним $€$ акцентування Ю. Фокіним на необхідності включення до змісту підготовки магістрів педагогічних спеціальностей як майбутніх викладачів або вчених підготовки до таких видів діяльності, у яких безсумнівно проявляються ознаки творчості: планування навчальних занять і їхня реалізація; застосування нових методичних прийомів, нове наповнення відомої дидактично наповненої операції; застосування відомих засобів навчання з розробкою нових дидактичних матеріалів для них, перетворення наукової інфрормації на навчальну, що відповідає рівню чи меті освіти; розробка окремої методики (методики викладання певної навчальної дисципліни); розробка нових методичних прийомів і засобів; розробка нових методів навчання (нових процедур, що потенційно забезпечують реалізацію мети навчання чи нових продуктів такої активності під наглядом педагога); уточнення чи розробка окремих категорій чи тверджень відомої теорії; теоретичне узагальнення досвіду та поглядів педагогів-попередників, втілення в сукупності взаємопов'язаних термінів і тверджень; розробка нової системи навчання та виховання для кожного рівня освіти [17, с. 202-204].

Г. Підкурганна, переосмислюючи підготовку майбутніх вихователів крізь призму становлення їхньої професійної компетентності та творчого мислення у процесі самостійного моделювання, проектування, конструювання, розглядає іiі а як творчий процес [13, с. 10]. Підтримуємо думку І. Княжевої, що саме педагогічна творчість сприяє підвищенню ефективності профресійної підготовки фахівців системи дошкільної освіти через створення простору для творчого самовизначення викладачів і студентів, розвитку в них здатності до самовдосконалення, опанування засобами творчого підходу до роботи [9, с. 3].

Підсумовуючи вищесказане, вважаємо, що головним завданням професійної підготовки майбутніх вихователів закладів дошкільної освіти є фрормування студентів як суб'єктів профресійної 
діяльності, носіїв готовності виконувати діяльність, відповідати за її результат, здійснення і розвиток, тобто бути ії̈ творцем. Вважаємо, що вирішення цього завдання можливе за умови оновлення змісту підготовки 3 педагогічних дисциплін 3 опорою на сучасні теоретико-методологічні концепції розвитку творчої особистості шляхом ознайомлення студентів із творчими освітніми технологіями, педагогічними інноваціями тощо.

Висновки. Отже, розглядаючи поняття творчого потенціалу, можна відзначити, що цей феномен неє сталим показником особистостіпедагога, а перебуває в постійному русі, фрормується на основі накопиченого ним творчого і соціального досвіду, психолого-педагогічних і предметних знань, нових ідей, умінь і навичок, що дозволяють знаходити і застосовувати оригінальні рішення, новаторські форми та методи ітим самим удосконалювати виконання своїх профресійних фрункцій. Творчий потенціал особистості майбутніх вихователів закладів дошкільної освіти розглядаємо як внутрішнє джерело активності, здатність до саморозвитку в умовах творчої діяльності у процесі професійної діяльності. Творче зростання дитини дошкільного віку можливе насамперед у взаємодії з творчим розвитком вихователя, що диктує завдання забезпечення його особистісного і профресійного зростання як суб'єкта профресійної діяльності.

\section{БІБЛІОГРАФІЧНИЙ СПИСОК:}

1. Алексеева М.А. Развитие творческого потенциала студентов в процессе обучения методике преподавания специальных дисциплин : дис. ... канд. пед. наук : 13.00.08. Кострома, 2002. 181 с.

2. Біла І.М. До вершин педагогічної майстерності. Дошкільне виховання, 2010. № 10. С. 3-5.

3. Большой энциклопедический словарь / гл. ред. А.М. Прохоров. Москва - Санкт-Петербург : Большая Российская Энциклопедия, 2001. 1434 с.

4. Гончаренко С. Український педагогічний словник. Київ : Либідь, 1997. 376 с.

5. Гопка О.М. Творчий потенціал особистості як наукова категорія. Науковий часопис Національного педагогічного університету імені М.П. Драгома- нова. Серія 16 : Творча особистість учителя: проблеми теорії і практики. 2016. Вип. 27 (37). С. 11-14.

6. Ємчик О.Г. Розвиток творчого потенціалу магістрів дошкільної освіти у процесі профресійної підготовки : дис.... канд. пед. наук : 13.00.04 / Рівненський державний гуманітарний університет. Луцьк, 2018. $318 \mathrm{c}$.

7. Злобіна О.Г. Особистість як суб'єкт соціальних змін : авторефр. дис. ... докт. соціол. наук : 22.00.03 / Нац. акад. наук України, Ін-т соціології. Київ, 2005. 32 с.

8. Клепіков О.І., Кучерявий І.Т. Основи творчості особи : навчальний посібник. Київ : Вища школа, 1996. 295 с.

9. Княжева І.А. Теоретико-методологічні засади розвитку методичної культури майбутніх викладачів педагогічних дисциплін в умовах магістратури : автореф. дис. ... докт. пед. наук : 13.00.04; 13.00.08. Одеса, 2014. 45 с.

10.Кремень В.Г. Трансформації особистості в освітньому просторі сучасної цивілізації. Педагогіка $i$ психологія. 2008. № 2 (59). С. 5-14.

11.Лихвар В.Д. Розвиток художньо-творчого потенціалу молодших школярів у процесі образотворчої діяльності : автореф. дис. ... канд. пед. наук : 13.00.07 / Херсон. держ. ун-т. Херсон, 2003. 24 с.

12. Лісовська Т. Проблема професійної підготовки майбутніх фрахівців 3 дошкільної освіти у вищих навчальних закладах. Науковий вісник Миколаївського національного університету імені B.О. Сухомлинського. Серія : Педагогічні науки. Вип. 2. 2016. C. 101-108.

13. Підкурганна Г.О. Теоретико-методологічні та методичні основи художньо-педагогічної підготовки студентів фракультету дошкільного виховання педагогічного університету : автореф. дис. ... докт. пед. наук : 13.00.04. Київ, 2003. 40 с.

14. Рубінштейн С.Л. Вибрані фрілософрсько-психологічні праці. Київ : Освіта, 1997. 127 с.

15. Сисоєва С.О. Основи педагогічної творчості : підручник. Київ : Міленіум, 2006. 344 с.

16. Сухомлинський В.О. Вибрані твори : В 5 т. Київ : Радянська школа, 1976. Т. І: Методика виховання колективу, 1976. 637 с.

17. Фокин Ю.Г. Преподавание и воспитание в высшей школе: Методология, цели и содержание, творчество : учебное пособие. Москва : Издательский центр «Академия», 2002. 224 с. 